\title{
Chemical and biological investigations of Delonix regia (Bojer ex Hook.) Raf.
}

\author{
ISRAT JAHAN $^{1}$ \\ MOHAMMAD S. RAHMAN ${ }^{2}$ \\ MOHAMMED Z. RAHMAN ${ }^{3}$ \\ MOHAMMAD A. KAISAR ${ }^{2}$ \\ MOHAMMAD S. ISLAM $^{1}$ \\ ABDUL WAHAB \\ MOHAMMAD A. RASHID ${ }^{2, *}$ \\ 1 Department of Clinical Pharmacy \\ and Pharmacology, Faculty of Pharmacy \\ University of Dhaka, Dhaka-1000 \\ Bangladesh \\ ${ }^{2}$ Department of Pharmaceutical \\ Chemistry, Faculty of Pharmacy \\ University of Dhaka \\ Dhaka-1000, Bangladesh \\ ${ }^{3}$ Department of Pharmacy \\ The University of Asia Pacific \\ Dhaka-1209, Bangladesh \\ ${ }^{4}$ Department of Skin and Veneral \\ Diseases, Bangabandhu Sheikh Mujib \\ Medical University, Shahbag \\ Dhaka-1000, Bangladesh
}

\begin{abstract}
In this study, five compounds, lupeol (1), epilupeol (2), $\beta$-sitosterol (3), stigmasterol (4) and $p$-methoxybenzaldehyde (5) were isolated from the petroleum ether and dichloromethane fractions of a methanolic extract of the stem bark of Delonix regia. Antimicrobial screening of the different extracts $\left(15 \mu \mathrm{g} \mathrm{mm}^{-2}\right)$ was conducted by the disc diffusion method. The zones of inhibition demonstrated by the petroleum ether, carbon tetrachloride and dichloromethane fractions ranged from 9-14 mm, 11-13 mm and 9-20 mm, respectively, compared to kanamycin standard with the zone of inhibition of 20-25 mm. In brine shrimp lethality bioassay, the carbon tetrachloride soluble materials demonstrated the highest toxicity with $L C_{50}$ of $0.83 \mu \mathrm{g} \mathrm{mL}^{-1}$, while petroleum ether and dichloromethane soluble partitionates of the methanolic extract revealed $L C_{50}$ of 14.94 and $3.29 \mu \mathrm{g} \mathrm{mL}^{-1}$, respectively, in comparison with standard vincristine sulphate with $L C_{50}$ of $0.812 \mu \mathrm{g} \mathrm{mL}-1$. This is the first report on compounds separation from $D$. regia, their antimicrobial activity and cytotoxicity.
\end{abstract}

Keywords: Delonix regia (Fabaceae), methanolic extract, antimicrobial activity, brine shrimp lethality

Delonix regia (Bojer ex Hook.) Raf. (Fabaceae) is an umbrella-shaped tree reaching up to 40 feet high and with large red-orange flowers. Its leaves are alternate, bipinnately compounded, having 10 to 20 pairs of major leaflets and fruits are $30-50 \mathrm{~cm}$ long. It grows all over Bangladesh and has folkloric reputation as a medicinal agent. D. regia is used as a diuretic, anthelmintic and astringent $(1,2)$. It is also used in leucorrhoea. Previous phytochemical investigations of D. regia revealed occurrences of auroxanthin,

\footnotetext{
*Correspondence; e-mail: rashidma@univdhaka.edu,rashid_phdu@yahoo.com
} 
mutatochrome and pyruvic acid (3). We herein report for the first time the isolation of lupeol (1), epilupeol (2), $\beta$-sitosterol (3), stigmasterol (4) and $p$-methoxybenzaldehyde (5) from a methanolic extract of $D$. regia (Bojer ex Hook.) Raf. as well as preliminary antimicrobial and toxic activities of the various extractives.

\section{EXPERIMENTAL}

\section{Instruments}

${ }^{1} \mathrm{H}$ NMR spectra were recorded using a Bruker AMX-400 (400 MHz) instrument and the spectra were referenced to the residual non-deuterated solvent $\left(\mathrm{CDCl}_{3}\right)$ signals. Column chromatography (CC) was conducted over (Merck) (Germany) silica gel (Kiesel gel $60 \mathrm{H}$, mesh 70-230 mm). Preparative TLC was carried out using normal-phase Si-gel 60 $\mathrm{PF}_{254}$ (Merck) on glass plates $(20 \times 20 \mathrm{~cm})$ of $0.5-\mathrm{mm}$ thickness. Spots on TLC and preparative TLC plates were visualized under UV light (254 and $366 \mathrm{~nm}$ ) after spraying with vanillin-sulfuric acid, followed by heating at $110{ }^{\circ} \mathrm{C}$ for $5-10$ minutes.

\section{Reagents}

Kanamycin standard discs were obtained from Oxoid Ltd. (Germany). Reagent grade methanol, petroleum-ether, carbon tetrachloride, dichloromethane, chloroform, ethyl acetate and toluene were procured from Merck.

Authentic samples of lupeol, epilupeol, stigmasterol and $\beta$-sitosterol were collected from Phytochemistry Research Laboratoty, Faculty of Pharmacy, University of Dhaka, Bangladesh. These compounds were isolated from plant sources (purity approximately $99 \%$ ) and their structures were confirmed by extensive spechroscopic testing.

\section{Plant material}

Stem bark of Delonix regia (Bojer ex Hook.) Raf. was collected from Dhaka in July 2004. A voucher specimen for this collection is maintained in the Bangladesh National Herbarium, Dhaka, Bangladesh.

\section{Extraction and isolation}

The air-dried and powdered stem bark $(1.0 \mathrm{~kg})$ of $D$. regia was soaked in $2.5 \mathrm{~L}$ of methanol for 10 days and then filtered through a cotton plug, followed by Whatman filter paper number 1 . The extract was concentrated with a rotary evaporator. An aliquot of the concentrated methanolic extract was fractionated by the modified Kupchan partitioning method (4) into petroleum ether, carbon tetrachloride, dichloromethane and aqueous soluble fractions. In brief, the methanolic extract $(5 \mathrm{~g})$ was dissolved in $100 \mathrm{~mL}$ of $10 \%$ aqueous methanol and extracted three times with $300 \mathrm{~mL}$ of petroleum ether. The polarity of the remaining aqueous-methanolic phase was then increased by adding $12.5 \mathrm{~mL}$ of water and extracted three times with $300 \mathrm{~mL}$ of carbontetrachloride. Finally, the remaining aqueous-methanolic phase was further increased in polarity by adding 16 
$\mathrm{mL}$ of water and extracted three times with $300 \mathrm{~mL}$ of dichloromethane. Subsequent evaporation of solvents yielded petroleum ether (PE, $0.60 \mathrm{~g})$, carbontetrachloride (CT, 1.50 $\mathrm{g})$, dichloromethane (DM $1.50 \mathrm{~g}$ ) and aqueous (AQ $1.10 \mathrm{~g}$ ) soluble materials, respectively.

The petroleum ether and dichloromethane soluble partitionates were separately chromatographed over silica gel and the columns were eluted with petroleum ether followed by mixtures of petroleum ether and ethyl acetate in order of increasing polarities to yield 120 fractions of 18-20 mL each. Compound 1 (lupeol) was isolated as a colorless crystalline product from column fractions no. 24-28 eluted with $10 \%$ ethyl acetate in petroleum ether. Preparative TLC (toluene/ethyl acetate $9: 1$ ) of the column fractions no. 41-46 afforded compound 3 ( $\beta$-sitosterol) as amorphous powder. Similar column chromatographic separation of dichloromethane soluble materials eluted with $20 \%$ ethyl acetate in petroleum ether afforded compound 2 (epilupeol) as white powder. Again, compounds 4 (stigmasterol) and 5 ( $p$-methoxybenzaldehyde) were purified from column fractions no. 58-60 and 71-73 upon re-chromatography over slica gel $\left(\mathrm{F}_{254}\right)$ with $5 \%$ and $10 \%$ ethyl acetate in toluene, respectively.

\section{Antimicrobial screening}

The disc diffusion method (5) was used to test the antimicrobial activity of extractives against thirteen bacteria (Bacillus cereus, B. megaterium, B. subtilis, Staphylococcus aureus, Sarcina lutea, Escherichia coli, Pseudomonas aeruginosa, Salmonella paratyphi, S. typhi, Shigella boydii, S. dysenteriae, Vibrio mimicus and V. parahemolyticus) and 3 fungi (Candida albicans, Aspergillus niger and Sacharomyces cerevisiae), collected as pure cultures from the Institute of Nutrition and Food Science (INFS), University of Dhaka, Bangladesh. Solutions of known concentrations of test samples (petroleum ether, carbontetrachloride and dichloromethane soluble fractions of the methanolic extract) were made by dissolving the samples in chloroform or methanol. Dried and sterilized filter paper discs $(6 \mathrm{~mm}$ diameter) were then impregnated with known amounts of test substances using a micropipette and the residual solvents were completely evaporated. Discs containing test materials were placed on nutrient agar medium uniformly seeded with test microorganisms. Standard disc of kanamycin $\left(1.06 \mu \mathrm{g} \mathrm{mm}^{-2}\right)$ and blank discs (impregnated with solvents, followed by evaporation) were used as positive and negative controls, respectively. The plates were then kept at low temperature $\left(4^{\circ} \mathrm{C}\right)$ for 24 hours to allow maximum diffusion of test materials and kanamycin. The plates were finally incubated at $37^{\circ} \mathrm{C}$ for 24 hours to allow maximum growth of the organisms. The antimicrobial activity of the test agents was determined by measuring the diameter of the zone of inhibition expressed in $\mathrm{mm}$. The experiment was carried out in triplicate, mean \pm SD was recorded.

\section{Brine shrimp lethality bioassay}

Brine shrimp lethality bioassay (6) technique was applied for the determination of general toxicity of plant extractives. Following the procedure of Meyer et al. (7), the lethality of the petroleum ether, carbon tetrachloride and dichloromethane soluble fractions of the methanolic extract was evaluated against brine shrimp, Artemia salina. 
Preparation of the positive control group. - Vincristine sulphate (VS) was used as the positive control. Vincristine sulphate was dissolved in DMSO to get an initial concentration of $20 \mu \mathrm{g} \mathrm{mL}^{-1}$, from which serial dilutions were made using DMSO, from 10 to $0.0390 \mu \mathrm{g} \mathrm{mL}^{-1}$. The solutions were then added to pre-marked vials containing ten live brine shrimp nauplii in $5 \mathrm{~mL}$ of simulated seawater.

Preparation of the negative control group. - DMSO $(100 \mu \mathrm{L})$ was added to each of the three pre-marked glass vials containing $5 \mathrm{~mL}$ of simulated seawater and 10 shrimp nauplii. If brine shrimps in the vials showed rapid mortality, then the test was considered invalid as the nauplii died from some reasons other than cytotoxicity of the compounds.

Preparation of test groups. - Each of the partitionates (4 mg) obtained by Kupchan fractionation was dissolved in DMSO and solutions of varying concentrations from 400 to $0.781 \mu \mathrm{g} \mathrm{mL}-1$ were obtained by serial dilution. The solutions were then added to the pre-marked vials containing ten live brine shrimp nauplii in $5 \mathrm{~mL}$ of simulated seawater.

Table I. Physicochemical and ${ }^{1} H$ NMR spectral data of lupeol (1), epilupeol (2), $\beta$-sitosterol (3) stigmasterol (4) and p-methoxybenzaldehyde (5) in $\mathrm{CDCl}_{3}$

\begin{tabular}{|c|c|c|c|c|c|}
\hline & 1 & 2 & 3 & 4 & 5 \\
\hline Yields (\%) & 0.20 & 0.08 & 0.40 & 0.60 & 0.10 \\
\hline $\begin{array}{c}\text { Physical } \\
\text { apprearance }\end{array}$ & $\begin{array}{l}\text { Colorless } \\
\text { crystalline mass }\end{array}$ & $\begin{array}{l}\text { White } \\
\text { powder }\end{array}$ & $\begin{array}{l}\text { Amorphous } \\
\text { powder }\end{array}$ & $\begin{array}{l}\text { Colorless } \\
\text { needles }\end{array}$ & $\begin{array}{c}\text { Amorphous } \\
\text { powder }\end{array}$ \\
\hline Proton position & \multicolumn{5}{|c|}{${ }^{1} \mathrm{H}$ NMR mult $\delta(\mathrm{ppm}), J(\mathrm{~Hz})$} \\
\hline 2 & & & & & $6.75, \mathrm{~d}(8.8)$ \\
\hline 3 & $3.20, \mathrm{dd}(11.5,5.03)$ & $3.37, \mathrm{t}(3.0)$ & $3.50, \mathrm{~m}$ & $3.51, \mathrm{~m}$ & $7.58, \mathrm{~d}(8.8)$ \\
\hline 6 & & & $5.34, \mathrm{~m}(7.0)$ & $5.35, \mathrm{~m}$ & \\
\hline 18 & & & $0.67, \mathrm{~s}$ & $0.67, \mathrm{~s}$ & \\
\hline 19 & $2.28, \mathrm{~m}$ & $2.28, \mathrm{~m}$ & $1.00, \mathrm{~s}$ & $1.00, \mathrm{~s}$ & \\
\hline 21 & & & $0.91, \mathrm{~d}(6.4)$ & $0.92, \mathrm{~d}(6.0)$ & \\
\hline 22 & & & & 5.14 , dd $(15.0,6.5)$ & \\
\hline 23 & $0.95, \mathrm{~s}$ & $0.95, \mathrm{~s}$ & & $5.04, \mathrm{dd}(15.0,9.0)$ & \\
\hline 24 & $0.78, \mathrm{~s}$ & $0.78, \mathrm{~s}$ & & & \\
\hline 25 & $0.84, \mathrm{~s}$ & $0.84, \mathrm{~s}$ & & & \\
\hline 26 & $1.02, \mathrm{~s}$ & $1.02, \mathrm{~s}$ & $0.83, \mathrm{~d}(6.0)$ & $0.84, \mathrm{~d}(6.0)$ & \\
\hline 27 & $0.93, \mathrm{~s}$ & $0.93, \mathrm{~s}$ & $0.81, \mathrm{~d}(6.0)$ & $0.82, \mathrm{~d}(6.0)$ & \\
\hline 28 & $0.82, \mathrm{~s}$ & $0.82, \mathrm{~s}$ & & & \\
\hline 29 & $\begin{array}{l}4.67 \text {, br. s } \\
4.55 \text {, br. s }\end{array}$ & $\begin{array}{l}4.67 \text {, br. s } \\
4.55 \text {, br. s }\end{array}$ & $0.85, \mathrm{~d}(6.0)$ & $0.82, \mathrm{t}(6.5)$ & \\
\hline 30 & $1.67, \mathrm{~s}$ & $1.67, \mathrm{~s}$ & & & \\
\hline $\mathrm{CHO}-4$ & & & & & $9.63, \mathrm{~s}$ \\
\hline $\mathrm{OCH}_{3}-1$ & & & & & $3.69, \mathrm{~s}$ \\
\hline
\end{tabular}


Counting of nauplii. - After 24 hours, the vials were inspected using a magnifying glass and the number of survived nauplii in each vial was counted. From this data, the percent $(\%)$ of lethality of the brine shrimp nauplii was calculated for each concentration. The median lethal concentration $\left(L C_{50}\right)$ of test samples was obtained by a plot the of percentage of shrimps killed against the logarithm of sample concentration. For each extract, three samples were prepared for each of the bioassays. $L C_{50}$ was calculated as mean $\pm \mathrm{SD}(n=3)$.

\section{RESULTS AND DISCUSSION}

Solvent-solvent partitioning, followed by repeated chromatographic separation and purification of the methanol extract of D. regia (Bojer ex Hook.) Raf., provided a total of five compounds (1-5) (Fig. 1). The structures of isolated compounds were solved by extensive NMR data analysis.

The ${ }^{1} \mathrm{H}$ NMR spectrum of compound 1 showed a double doublet $(J=11.5,5.03 \mathrm{~Hz})$ of one proton intensity at $\delta 3.20 \mathrm{ppm}$, typical of an oxymethine proton at C-3 of a triterpene. The splitting pattern of this proton confirmed the $\beta$ orientation of the C-3 oxygenated substituent. The spectrum also displayed two singlets at $\delta 4.67$ and $4.55 \mathrm{ppm}$ $\left(1 \mathrm{H}\right.$ each) assignable to the vinylic protons at C-29. The ${ }^{1} \mathrm{H}$ NMR spectrum showed seven singlets at $\delta 0.95,0.78,0.84,1.02,0.93,0.82$ and $1.67 \mathrm{ppm}(3 \mathrm{H}$ each) assignable to methyl group protons at C-4 $\left(\mathrm{H}_{3}-23, \mathrm{H}_{3}-24\right), \mathrm{C}-10\left(\mathrm{H}_{3}-25\right), \mathrm{C}-8\left(\mathrm{H}_{3}-26\right), \mathrm{C}-14\left(\mathrm{H}_{3}-27\right)$, $\mathrm{C}-17\left(\mathrm{H}_{3}-28\right)$ and $\mathrm{C}-20\left(\mathrm{H}_{3}-30\right)$, respectively. By comparing the ${ }^{1} \mathrm{H}$ NMR data with previously published data (8), compound $\mathbf{1}$ was identified as lupeol. The identity of $\mathbf{1}$ was further substantiated by co-TLC with an authentic sample of lupeol.

The ${ }^{1} \mathrm{H}$ NMR spectrum of compound 2 showed a triplet $(J=3.0 \mathrm{~Hz})$ of one proton intensity at $\delta 3.37 \mathrm{ppm}$ characteristic of $\mathrm{H}-3$ of a terpene type carbon skeleton. The ab-
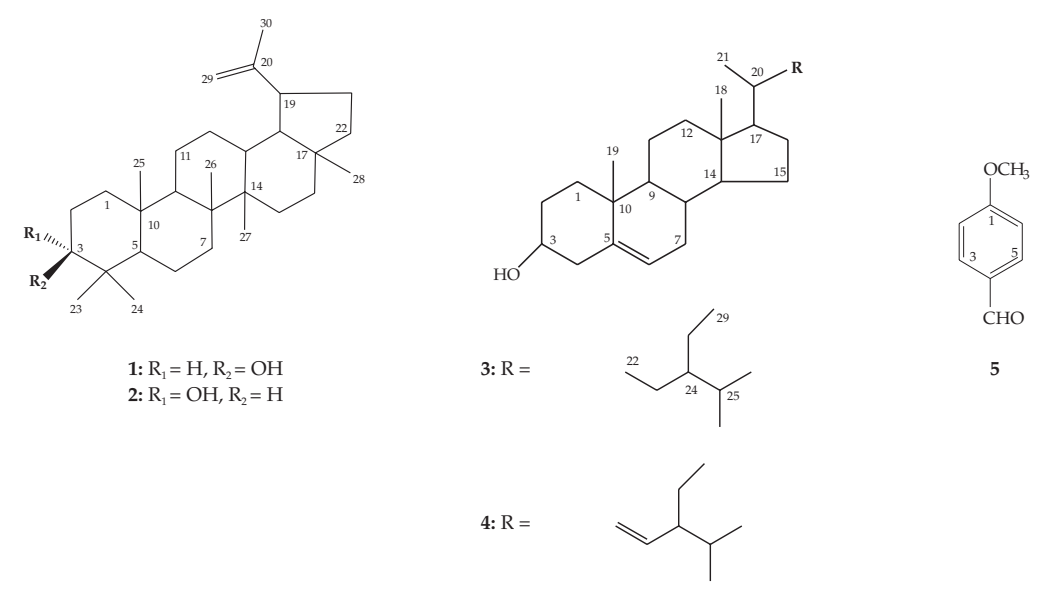

Fig. 1. Structures of the compounds isolated from Delonix regia. 
sence of a double doublet and the appearance of a triplet suggested that the hydroxy group was at $\alpha$-position, thus confirming the $\beta$ orientation of the $C-3$ proton (9). The spectrum displayed two singlets at $\delta 4.67$ and $4.55 \mathrm{ppm}(1 \mathrm{H}$ each) assignable to the vinylic protons at C-29. The multiplet at $\delta 2.28$ could be ascribed to the proton at C-19. The spectrum also displayed seven singlets at $\delta 0.95,0.78,0.84,1.02,0.93,0.82$ and 1.67 ppm (3H each) for methyl protons at C-4 $\left(\mathrm{H}_{3}-23, \mathrm{H}_{3}-24\right), \mathrm{C}-10\left(\mathrm{H}_{3}-25\right), \mathrm{C}-8\left(\mathrm{H}_{3}-26\right), \mathrm{C}-14$ $\left(\mathrm{H}_{3}-27\right), \mathrm{C}-17\left(\mathrm{H}_{3}-28\right)$ and $\mathrm{C}-20\left(\mathrm{H}_{3}-30\right)$, respectively. On this basis and by comparing these ${ }^{1} \mathrm{H}$ NMR data with previously published values (9), compound 2 was characterized as epilupeol. The identity of $\mathbf{2}$ as epilupeol was further substantiated by co-TLC with an authentic sample.

The ${ }^{1} \mathrm{H}$ NMR spectra of compounds 3 and 4 readily demonstrated the steroidal nature of these compounds. The spectral data of compounds 3 and 4 were superimposable to the ${ }^{1} \mathrm{H}$ NMR spectral data published for $\beta$-sitosterol (10) and stigmasterol (11). Addi-

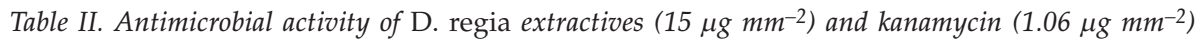

\begin{tabular}{|c|c|c|c|c|c|}
\hline \multirow{2}{*}{\multicolumn{2}{|c|}{ Test microorganism }} & \multicolumn{4}{|c|}{ Diameter of zone of inhibition (mm) } \\
\hline & & \multirow[t]{2}{*}{$\mathrm{PE}$} & \multirow[t]{2}{*}{$\mathrm{CT}$} & \multirow[t]{2}{*}{$\mathrm{DM}$} & \multirow[t]{2}{*}{ KAN } \\
\hline Gram positive bacteria & & & & & \\
\hline Bacillus cereus & QL 29 & - & - & $9 \pm 1$ & $25 \pm 1$ \\
\hline B. megaterium & QL 28 & - & - & $10 \pm 1$ & $24 \pm 0.3$ \\
\hline B. subtilis & QL 40 & $9 \pm 1$ & - & $13 \pm 1$ & $23 \pm 1$ \\
\hline Staphylococcus aureus & ATCC 25923 & - & - & $14 \pm 1$ & $25 \pm 1$ \\
\hline Sarcina lutea & QL 166 & $10 \pm 0.3$ & - & $12 \pm 1$ & $24 \pm 2$ \\
\hline \multicolumn{6}{|l|}{ Gram negative bacteria } \\
\hline Escherichia coli & ATCC 25922 & - & - & $15 \pm 1$ & $22 \pm 2$ \\
\hline Pseudomonas aeruginosa & ATCC 27853 & $14 \pm 1$ & $12 \pm 1$ & $10 \pm 1$ & $20 \pm 1$ \\
\hline Salmonella paratyphi & A AM 16590 & $12 \pm 0.3$ & $13 \pm 1$ & $20 \pm 1$ & $25 \pm 1$ \\
\hline S. typhi & AM 16406 & - & - & $16 \pm 2$ & $25 \pm 1$ \\
\hline Shigella boydii & ATCC 13/47 & - & - & $12 \pm 1$ & $20 \pm 1$ \\
\hline S. dysenteriae & ATCC 26/31 & $12 \pm 1$ & - & $14 \pm 2$ & $25 \pm 2$ \\
\hline Vibrio mimicus & N 1967 & - & $11 \pm 0.4$ & - & $28 \pm 1$ \\
\hline V. parahemolyticus & AM 16362 & - & - & $13 \pm 2$ & $25 \pm 1$ \\
\hline \multicolumn{6}{|l|}{ Fungi } \\
\hline Candida albicans & ATCC 10231 & $12 \pm 1$ & - & $11 \pm 2$ & $25 \pm 1$ \\
\hline Aspergillus niger & ATCC 1055 & - & - & - & $25 \pm 1$ \\
\hline Sacharomyces cerevisiae & AB 972 & $10 \pm 2$ & - & $14 \pm 1$ & $20 \pm 1$ \\
\hline
\end{tabular}

Diameters of the zone of inhibition are expressed as mean $\pm \operatorname{SD}(n=3)$.

$\mathrm{PE}$ - petroleum ether soluble fraction of the methanolic extract, CT - carbon tetrachloride soluble fraction of the methanolic extract, DM - dichloromethane soluble fraction of the methanolic extract, KAN - standard kanamycin. A diameter of zone of the inhibition less than $8 \mathrm{~mm}$ was considered inactive. 
Table III. $\mathrm{LC}_{50}$ data of test samples of D. regia

\begin{tabular}{cc}
\hline Sample & $L C_{50}\left(\mu \mathrm{g} \mathrm{mL}^{-1}\right)$ \\
\hline VS & $0.81 \pm 0.33$ \\
PE & $14.94 \pm 1.11$ \\
CT & $0.831 \pm 1.34$ \\
DM & $3.29 \pm 0.94$ \\
\hline
\end{tabular}

$L C_{50}$ values are expressed as mean $\pm \mathrm{SD}(n=3)$.

VS - vincristine sulphate (std.), PE - petroleum ether soluble fraction of the methanolic extract, CT - carbon tetrachloride soluble fraction of the methanolic extract, DM - dichloromethane soluble fraction of the methanolic extract.

tionally, thin layer chromatographic analysis of 3 and 4 with authentic samples of $\beta$-sitosterol and stigmasterol, respectively, also confirmed their identity.

The ${ }^{1} \mathrm{H}$ NMR spectrum of compound 5 showed a sharp downfield singlet at $\delta 9.63$ ppm characteristic of an aldehyde group proton. It also showed two doublets $(J=8.8$ $\mathrm{Hz}$ ) centered at $\delta 6.75$ and $7.58 \mathrm{ppm}$ (each $2 \mathrm{H}$ ), which could be assigned to the ortho coupled aromatic protons at C-2 and C-6, C-3 and C-5, respectively. The singlet of three proton intensity at $\delta 3.69 \mathrm{ppm}$ was demonstrative of a methoxyl group proton. These ${ }^{1} \mathrm{H}$ NMR data suggested that the compound must be a $p$-disubstituted benzene, where one of the substituents was an aldehydic group and the other substituent was a methoxyl function. On this basis and by comparing these values with published data (12), compound $\mathbf{5}$ was characterized as $p$-methoxybenzaldehyde.

In antimicrobial screening, the petroleum ether, carbon tetrachloride and dichloromethane soluble fractions of the crude methanolic extract showed average zones of inhibition of 9-14, 11-13 and 9-20 mm, respectively, compared to standard kanamycin with zone of inhibitions of 20-25 mm; no inhibition was observed in the case of negative control (Table II). The dichloromethane soluble fraction of the methanolic extract strongly inhibited the growth of $S$. paratyphi having the zone of inhibition of $20 \mathrm{~mm}$. The growth of $S$. typhi $(16 \mathrm{~mm}), S$. aureus $(14 \mathrm{~mm})$ and $S$. dysenteriae $(14 \mathrm{~mm})$ was moderately inhibited. On the other hand, the petroleum ether and carbon tetrachloride soluble fractions of the methanolic extract moderately inhibited the growth of $P$. aeruginosa $(14 \mathrm{~mm})$ and $S$. paratyphi $(13 \mathrm{~mm})$, respectively. In case of fungi, the growth of $S$. cerevisiae $(14 \mathrm{~mm})$ was moderately inhibited by dichloromethane soluble materials. The petroleum ether soluble fraction inhibited the growth of $C$. albicans and S. cerevisiae having the zone of inhibition of 12 and $10 \mathrm{~mm}$, respectively.

Table III shows the results of brine shrimp lethality testing after 24 hours of exposure to the samples and the positive control, vincristine sulphate. The $L C_{50}$ values were found to be 0.83 and $0.81 \mu \mathrm{g} \mathrm{mL}^{-1}$ for CT and VS, respectively. The toxicity exhibited by the carbontetrachloride soluble fraction of the methanolic extract was comparable to that of the positive control (vincristine sulphate).

It is evident that the carbon tetrachloride soluble partitionate of the methanolic extract showed highest toxicity while the dichloromethane soluble fraction of the methanolic extract exhibited significant antimicrobial activity. 


\section{CONCLUSIONS}

Four triterpenes, lupeol (1), epilupeol (2), $\beta$-sitosterol (3) stigmasterol (4) and an aromatic compound $p$-methoxybenzaldehyde (5) were isolated from the stem bark of Delonix regia (Bojer ex Hook.) Raf. Extractives of the plant species revealed possible antimicrobial activity and general toxicity, which might indicate the presence of bioactive principles in the plant. Further investigation is required to explore its effects on various diseases.

Acknowledgements. - We thank the Centre for Biomedical Research, University of Dhaka, Dhaka, Bangladesh, for providing some laboratory facilities for carrying out the research.

\section{REFERENCES}

1. F. M. Maniruzzaman, A Compendium of Plants in Bangladesh, $1^{\text {st }}$ ed., Bangla Academy, Dhaka, 1993, p. 262.

2. O. Lawal, N. E. Uzokwe, A. B. I. Igboanugo, A. F. Adio, E. A. Awosan, J. O. Nwogwugwu, B. Faloye, B. P. Olatunji and A. A. Adesoga, Ethno medicinal information on collation and identification of some medicinal plants in Research Institutes of South-west Nigeria, Afr. J. Pharm. Pharmacol. 4 (2010) 1-7.

3. F. B. Jungalwala and H. R. Cama, Carotenoids in Delonix regia (GulMohr) flower, Biochem. J. 85 (1962) 1-8.

4. B. C. Vanwagenen, R. Larsen, J. H. Cardellina II, D. Randazzo, Z. C. Lidert and C. Swithenbank, Ulosantoin, a potent insecticide from the sponge Ulosa ruetzleri, J. Org. Chem. 58 (1993) 335-337, DOI: org/10.1021/jo00054a013.

5. A. W. Bauer, W. M. M. Kirby, J. C. Sherris and M. Turck, Antibiotic susceptibility testing by a standardized single disc method, Am. J. Clin. Pathol. 45 (1966) 493-496.

6. J. L. McLaughlin and L. L. Rogers, The use of biological assays to evaluate botanicals, Drug Info. J. 32 (1998) 513-524.

7. B. N. Meyer, N. R. Ferrigni, J. E. Putnam, J. B. Jacobsen, D. E. Nicholsand, J. L. McLaughlin, Brine shrimp: a convenient general bioassay for active plant constituents, Planta Med. 45 (1982) $31-34$.

8. Y. Aratanechemuge, H. Hibasami, K. Sanpin, H. Katsuzaki, K. Imail and T. Komiya, Induction of apoptosis by lupeol isolated from mokumen (Gossampinus malabarica L. Merr) in human promyelotic leukemia HL-60 cells, J. Oncol. Rep. 11 (2004) 289-292.

9. M. Z. Rahman, S. J. Sultana, C. F. Faruquee, F. Ferdous, M. S. Rahman, M. S. Islam and M. A. Rashid, Phytochemical and biological investigations of Erythrina variegata, Saudi Pharm. J. 15 (2007) 140-145.

10. G. Morales, P. Sierra, A. Mancilla, A. Paredes, L. A. Loyola, O. Gallardo and J. Borquez, Secondary metabolites from four medicinal plants from northern Chile: antimicrobial activity and biotoxicity against Artemia salina, J. Chil. Chem. Soc. 48 (2003) 13-18; DOI: org/10.4067/S0717-97072003000200002 .

11. U. Kolak, G. Topcu, S. Birteksoz, G. Otuk and A. Ulubelen, Terpenoids and steroids from the roots of Salvia blepharochlaena, Turk. J. Chem. 29 (2005) 177-186. 
12. R. Harish, S. Divakar, A. Srivatava and T. Shivanandappa, Isolation of antioxidant compounds from the methanolic extract of the roots of Decalepis hamiltonii (Wight and Arn.), J. Agric. Food Chem. 53 (2005) 7709-7714; DOI: org/10.1021/jf051047c.

\section{$S A \check{Z} E T A K$}

\section{Kemijsko i biološko ispitivanje biljke Delonix regia (Bojer ex Hook.) Raf.}

ISRAT JAHAN, MOHAMMAD S. RAHMAN, MOHAMMED Z. RAHMAN, MOHAMMAD A. KAISAR, MOHAMMAD S. ISLAM, ABDUL WAHAB i MOHAMMAD A. RASHID

U radu je opisana izolacija pet sastojaka petroleterske i diklormetanske frakcije metanolnog ekstrakta kore biljke Delonix regia: lupeol (1), epilupeol (2), $\beta$-sitosterol (3), stigmasterol (4) i $p$-metoksibenzaldehid (5). Nadalje, testirano je antimikrobno djelovanje različitih ekstrakata difuzijskom metodom na disku $\left(15 \mu \mathrm{g} \mathrm{mm}{ }^{-2}\right)$. Zone inhibicije za sastojke topljive $u$ petroleteru, tetraklormetanu i diklormetanu bile su 9-14 mm, 11-13 $\mathrm{mm}$, odnosno 9-20 mm, dok je zona inhibicije standarda kanamicina bila 20-25 mm. U biološkom pokusu smrtnosti morskih kozica najveću toksičnost pokazali su spojevi topljivi u tetraklormetanu $\left(L C_{50}=0,83 \mu \mathrm{g} \mathrm{mL}-1\right)$, dok je topljivost sastojaka topljivih $\mathrm{u}$ petroleteru i diklormetanu bila $L C_{50} 14,94$, odnosno $3,29 \mu \mathrm{g} \mathrm{mL}^{-1}$, a standarda vinkristin sulfata $0,812 \mu \mathrm{g} \mathrm{mL}^{-1}$. Ovo je prvo izvješće o izolaciji sastojaka, antimikrobnom djelovanju i citotoksičnosti biljke $D$. regia.

Ključne riječi: Delonix regia (Fabaceae), metanolni ekstrakt, antimikrobno djelovanje, smrtnost morskih kozica

Department of Clinical Pharmacy and Pharmacology, Faculty of Pharmacy, University of Dhaka, Dhaka-1000, Bangladesh

Department of Pharmaceutical Chemistry, Faculty of Pharmacy, University of Dhaka, Dhaka-1000, Bangladesh

Department of Pharmacy, The University of Asia Pacific, Dhaka-1209, Bangladesh

Department of Skin \& Veneral Diseases, Bangabandhu Sheikh Mujib Medical University, Shahbag, Dhaka-1000, Bangladesh 